\title{
CD24 cross-linking induces apoptosis in, and inhibits migration of, MCF-7 breast cancer cells
}

Jong Bin Kim ${ }^{\dagger 1}$, Eunyoung Ko ${ }^{\dagger 2}$, Wonshik Han², Jeong Eon Lee ${ }^{2}$, KyungMin Lee ${ }^{1}$, Incheol Shin ${ }^{3}$, Sangmin Kim${ }^{4}$, Jong Won Lee ${ }^{2}$, Jihyoung Cho², JiYeon Bae ${ }^{1}$, Hyeon-Gun Jee ${ }^{1}$ and Dong-Young Noh*1,2

\begin{abstract}
Address: ${ }^{1}$ Cancer Research Institute, Seoul National University College of Medicine, 28 Yongon-dong, Chongno-gu, Seoul 110-744, Korea ${ }^{2}$ Department of Surgery, Seoul National University College of Medicine, 28 Yongon-dong, Chongno-gu, Seoul 110-744, Korea, ${ }^{3}$ Department of Life Science, College of Natural Sciences, Hanyang University, 17 Haengdang-dong, Sungdong-gu, Seoul 133-791, Korea and ${ }^{4}$ Clinical Research Institute, Seoul National University College of Medicine, 28 Yongon-dong, Chongno-gu, Seoul 110-744, Korea

Email: Jong Bin Kim - kkimjp@hanmail.net; Eunyoung Ko - mooloo@medimail.co.kr; Wonshik Han - hanw@snu.ac.kr; Jeong Eon Lee - paojlus@hanmail.net; Kyung-Min Lee - km601@hanmail.net; Incheol Shin - incheol@hanyang.ac.kr; Sangmin Kim - ksm3005@snu.ac.kr; Jong Won Lee - jwlee@medimail.co.kr; Jihyoung Cho - chojh0404@hanmail.net; JiYeon Bae - jita94@hanmail.net; Hyeon-Gun Jee - wookieneo@naver.com; Dong-Young Noh* - dynoh@snu.ac.kr

* Corresponding author †Equal contributors
\end{abstract}

Published: 24 April 2008

BMC Cancer 2008, 8: 118 doi:10.1186/147|-2407-8-118

This article is available from: http://www.biomedcentral.com/I47I-2407/8/II8

(C) 2008 Kim et al; licensee BioMed Central Ltd.

This is an Open Access article distributed under the terms of the Creative Commons Attribution License (http://creativecommons.org/licenses/by/2.0), which permits unrestricted use, distribution, and reproduction in any medium, provided the original work is properly cited.

\begin{abstract}
Background: The biological effects of CD24 (FL-80) cross-linking on breast cancer cells have not yet been established. We examined the impact of CD24 cross-linking on human breast cancer cell line MCF-7.

Methods: MCF-7 and MDA-MB-23I cells were treated with anti-rabbit polyclonal lgG or antihuman CD24 rabbit polyclonal antibodies to induce cross-linking, and then growth was studied. Changes in cell characteristics such as cell cycle modulation, cell death, survival in threedimensional cultures, adhesion, and migration ability were assayed after CD24 cross-linking in MCF-7.

Results: Expression of CD24 was analyzed by flow cytometry in MDA-MB-23I and MCF-7 cells where $2 \%$ and $66 \%$ expression frequencies were observed, respectively. CD24 cross-linking resulted in time-dependent proliferation reduction in MCF-7 cells, but no reduction in MDA-MB$23 \mathrm{I}$ cells. MCF-7 cell survival was reduced by $15 \%$ in three-dimensional culture after CD24 crosslinking. Increased MCF-7 cell apoptosis was observed after CD24 cross-linking, but no cell cycle arrest was observed in that condition. The migration capacity of MCF-7 cells was diminished by $30 \%$ after CD24 cross-linking.
\end{abstract}

Conclusion: Our results showed that CD24 cross-linking induced apoptosis and inhibited migration in MCF-7 breast cancer cells. We conclude that CD24 may be considered as a novel therapeutic target for breast cancer. 


\section{Background}

CD24 is expressed in hematopoietic cell types, including B-cell precursors and neutrophils [1], and is also conventionally used as a differentiation marker for keratinocytes [2]. Accumulating evidence supports a role for CD24 in a variety of malignancies, including B-cell lymphoma, renal cell carcinoma, small-cell and non small-cell lung carcinoma, nasopharyngeal carcinoma, hepatocellular carcinoma, bladder carcinoma, epithelial ovarian cancer and breast cancer [3].

CD24, designated 'heat-stable antigen' (HSA) in mice, is a glycosylated cell-surface protein linked to the membrane via a glycosyl-phosphatidylinositol (GPI) anchor [4]. CD24 has several potential $\mathrm{N}$ - and O-linked glycosylation sites, which act as ligands for P-selectin [4].

CD24 is involved in cellular adhesion processes and signalling pathways in cancer cells that are dependent on interactions with P-selectin [4]. Moreover, CD24-mediated binding to P-selectin on endothelial cells and platelets may facilitate the exit of tumor cells from the bloodstream and potentiate metastasis [3]. In P-selectindeficient mice, diminished tumor growth and metastasis is observed, compared with wild-type animals [5]. Moreover, CD24 over-expression is associated with invasiveness in urothelial carcinoma [6] and with migration and invasion in gliomas [7]. These studies collectively imply that CD24 might play an important role in tumorigenesis and in the progression of cancer. Moreover, CD24 expression is suggested to be a marker of poor prognosis in various cancers, including breast carcinoma [8]. In breast cancer, CD24 mediates progression, metastasis, and rolling of tumor cells through interactions with P-selectin [9]. Additionally, CD24 function may be related to tamoxifen resistance [10]. In this study, MCF-7 cells were used as a general breast cancer cell model, based on the fact that these cells are derived from a pleural effusion from a patient with metastatic breast carcinoma [11]. MCF-7 cells are adherent, and they aggregate into clusters under standard culture conditions to form duct like structures that mimic luminal structures observed in under three-dimensional culture conditions [12]. For this reason, MCF-7 cells have primarily been used as model of the luminal breast cancer cell type, which express CK8/18 [13], CK19 [14], CD24 [15] and the estrogen receptor [16], but not vimentin [11].

Recently, CD24 was recommended as a prognostic indicator of poor patient survival in breast cancer [17]. It is known that CD24 mRNA becomes unregulated after amino acid starvation in MCF-7 cells and that the CD24 protein is expressed more than $80 \%$ in MCF-7 cells [15]. For this reason it is suggested that CD24 may play an important role in the progression and metastasis of human breast cancer $[8,18]$.

The aim of this study was to further clarify the role of CD24 in breast cancer cell growth using a cross-linking approach. Changes in viable cell number, on adhesion and migration abilities, and in cell growth and death were assessed. We did to study directly impact on cross-linking with CD24 (FL-80) antibody in MCF-7 human breast cancer cell line.

\section{Methods \\ Cell culture}

Unless otherwise specified, all reagents were purchased from Sigma (St. Louis, MO). MDA-MB-231 and MCF-7 cell lines were cultured in Dulbecco's modified Eagle's medium (DMEM) containing 10\% fetal bovine serum (FBS). For the anchorage-dependent culture, $5 \times 10^{5}$ cells were seeded on a tissue culture dish (Falcon, San Jose, CA). Cells were incubated at $37^{\circ} \mathrm{C}$ in a humidified atmosphere containing $5 \% \mathrm{CO}^{2}$. Photographs were obtained with an inverted system microscope (IX51 model) equipped with a DP50 camera system (Olympus, Tokyo, Japan).

\section{CD24 expression in breast cell lines}

To detach MDA-MB-231 and MCF-7 cells, cultures were trypsinized for 3 min to minimize growth inhibition, and detachment was monitored with a phase-contrast microscope. After visual identification of detached cells, $5 \mathrm{ml}$ of medium containing serum was added to the culture for trypsin inactivation. Cells were collected by centrifugation, and washed with $5 \mathrm{ml}$ of PBS. Following a second centrifugation step, pellets were resuspended in $500 \mu \mathrm{l}$ total volume with the appropriate amounts of antibodies and supplement of PBS. The PE anti-human CD24 antibody (BD Pharmingen, NJ, USA) was applied according to the manufacturer's manual. After antibody binding for 25 min at room temperature, cells were rinsed three times with PBS and flow cytometry analyses were performed in triplicate using a FACSCalibur system (Becton \& Dickinson, San Jose, CA).

\section{Assessment of changes in proliferation of MDA-MB-23 I and MCF-7 cells upon CD24 cross-linking}

For each line, $5 \times 10^{5}$ cells were seeded with DMEM containing $10 \%$ FBS and after $24 \mathrm{~h}$, they were washed twice with PBS. Fresh DMEM+10\% FBS was added to the dish, and CD24 was cross-linked with anti-rabbit polyclonal IgG antibody and anti-human CD24 (FL-80) rabbit polyclonal antibody (Santa Cruz Biotechnology, Franklin Lakes, NJ). Rabbit-polyclonal anti-CD24 (FL-80) antibody was raised against amino acids $1-80$, representing full length CD24 of human origin. For each condition, the 
number of viable cells was estimated by trypan blue staining.

\section{Three-dimensional matrigel culture, and MTT assays}

For a three-dimensional culture, a millicell (millipore, Billerica, MA, USA) of $3 \mu \mathrm{m}$ pore size was coated with 5 $\mathrm{mg} / \mathrm{ml}$ matrigel (BD Pharmingen, NJ, USA) on a 6-well plate at $37^{\circ} \mathrm{C}$ for $1 \mathrm{~h}$. MCF-7 cells were trypsinized and seeded onto millicells in a dose dependent manner of $1 \times 10^{5}, 3 \times 10^{5}$, or $5 \times 10^{5}$ cells at $37^{\circ} \mathrm{C}$ for $24 \mathrm{~h}$. After $24 \mathrm{~h}$, cells cross-linked with anti-rabbit polyclonal IgG (500 ng/ $\mathrm{ml}$ ) or anti-human CD24 (FL-80) rabbit polyclonal antibody $(500 \mathrm{ng} / \mathrm{ml})$ at $37^{\circ} \mathrm{C}$ for $72 \mathrm{~h}$, then the media was removed. $100 \mu \mathrm{l}$ of MTT reagents $(5 \mathrm{mg} / \mathrm{ml})$ were added to each millicell, whch was incubated at $37^{\circ} \mathrm{C}$ for $3 \mathrm{~h}$ and the media was removed. $200 \mu \mathrm{l}$ of dimethylsulphoxide (DMSO) was then added to each millicell with shaking for $10 \mathrm{~min}$ and the absorbance was measured spectrophotometrically at $595 \mathrm{~nm}$.

\section{Cell cycle analysis and Annexin $\mathbf{V}$ staining}

After cross-linking for $72 \mathrm{~h}$, the MCF-7 culture was harvested, where cells were fixed in $70 \%$ ethanol for $1 \mathrm{~h}$, and washed with PBS. Cells were then treated with $100 \mu \mathrm{g} / \mathrm{ml}$ RNase A for $1 \mathrm{~h}$ at $37^{\circ} \mathrm{C}$, followed by $25 \mu \mathrm{g} / \mathrm{ml}$ propidium iodide solution. Flow cytometry was then performed in triplicate for each experiment on a FACSCalibur system (Becton \& Dickinson, San Jose, CA). Annexin V staining was done according to the manufacturer's protocol (BD Pharmingen, NJ, USA). MCF-7 cells were washed with PBS and trypsinized. After centrifugation, cells were washed twice with cold PBS, and resuspended in binding buffer (10 mM HEPES, pH 7.4, $150 \mathrm{mM} \mathrm{NaCl}, 5 \mathrm{mM} \mathrm{KCl}, 1 \mathrm{mM}$ $\left.\mathrm{MgCl}_{2}, 1.8 \mathrm{mM} \mathrm{CaCl}_{2}\right)$ at a concentration of $1 \times 10^{6}$ cells/ $\mathrm{ml}$. An aliquot $(100 \mu \mathrm{l})$ of the solution containing $1 \times 10^{5}$ cells was transferred to a $5 \mathrm{ml}$ culture tube, and $5 \mu \mathrm{l}$ each of Annexin V-FITC and PI were added. After vortexing, cells were incubated for $15 \mathrm{~min}$ at room temperature $\left(25^{\circ} \mathrm{C}\right)$ in the dark, and $400 \mu \mathrm{l}$ of $1 \times$ binding buffer was added to each tube. Flow cytometry was performed on a FACSCalibur system (Becton \& Dickinson, San Jose, CA) within $1 \mathrm{~h}$.

\section{Adhesion assay}

For adhesion assay, a 96-well plate was coated with type I collagen $(10 \mu \mathrm{g} / \mathrm{ml})$ at $37^{\circ} \mathrm{C}$ for $1 \mathrm{~h}$, washed twice with PBS, and blocked with $10 \%$ FBS in PBS. MCF-7 cells were seeded and incubated with anti-rabbit polyclonal IgG (500 ng/ml) or anti-human CD24 rabbit polyclonal antibody $(500 \mathrm{ng} / \mathrm{ml})$ at $37^{\circ} \mathrm{C}$ for $24 \mathrm{~h}$. After $24 \mathrm{~h}$, MCF-7 cells were washed twice with PBS and trypsinized, then seeded at $2 \times 10^{4} /$ well and incubated at $37^{\circ} \mathrm{C}$ incubator for $24 \mathrm{~h}$. Adherent cells were fixed with 3.7\% paraformaldehyde at room temperature for $20 \mathrm{~min}$, and cells were airdried for $5 \mathrm{~min}$, followed by staining with $0.1 \%$ crystal violet in methanol at room temperature for $45 \mathrm{~min}$. Cells were washed three times with PBS, and rinsed with $0.1 \mathrm{M}$ sodium citrate at room temperature for $30 \mathrm{~min}$. The absorbance of the resulting solution was measured at 595 $\mathrm{nm}$.

\section{Migration assay}

The migration assay was performed following the manufacturer's protocol (BD Pharmingen, NJ, USA). MCF-7 cells were pre-treated with anti-rabbit polyclonal IgG (500 $\mathrm{ng} / \mathrm{ml}$ ) or anti-human CD24 rabbit polyclonal antibody $\left(500 \mathrm{ng} / \mathrm{ml}\right.$ ) at $37^{\circ} \mathrm{C}$ for $24 \mathrm{~h}$. $2 \times 10^{4} /$ well cells were seeded onto the upper side of a transwell chamber (BD Pharmingen, NJ, USA) and incubated at $37^{\circ} \mathrm{C}$ for $24 \mathrm{~h}$. Cells from the upper side of the transwell were then scraped off mechanically, fixed with $100 \%$ methanol at room temperature for 2 min and stained with $1 \%$ toluidine blue in $1 \%$ borax solution at room temperature for 2 min and then counted with an inverted system microscope.

\section{Statistical analysis}

All data were compiled from a minimum of three replicate experiments. Data for statistical analysis were expressed as the mean \pm standard error. Comparison of results from treated versus control cells was done using $t$-stests. $p$ values of less than 0.05 were considered statistically significant.

\section{Results}

\section{CD24 expression in MDA-MB-23I and MCF-7 cells}

Expression of CD24 was analyzed in MDA-MB-231 and MCF-7 cells by flow cytometry, which revealed that $2 \%$ of MDA-MB-231 cells and 66\% of MCF-7 cells expressed CD24 (Fig. 1). Based on this result, we selected MDA-MB231 as negative control and MCF-7 as an experimental cell line for examining the effect of CD24 cross-linking on the growth of breast cancer cells.

\section{Proliferation of control and MCF-7 cells upon CD24 cross- linking}

$72 \mathrm{~h}$ after cross-linking, the number of viable cells was counted to analyze the effects of cross-linking on cell growth. MCF-7 cell viability did not change after crosslinking with $500 \mathrm{ng} / \mathrm{ml}$ anti-rabbit polyclonal IgG. However, cell viability after $72 \mathrm{~h}$ was reduced by $75 \%$ and $96 \%$ at antibody concentrations of $1 \mu \mathrm{g} / \mathrm{ml}$ and $2 \mu \mathrm{g} / \mathrm{ml}$, respectively (Fig. 2A). We also examined cell growth in five different culture media: culture medium without distilled water, culture medium with $0.025 \%$ distilled water, distilled water with $0.00025 \%$ sodium azide, distilled water with $0.00025 \%$ gelatin, and distilled water with $0.00025 \%$ PBS. We did not find difference in cell growth in each culture condition (Data not shown). Accordingly, $500 \mathrm{ng} / \mathrm{ml}$ was selected as the dose of anti-rabbit polyclo 

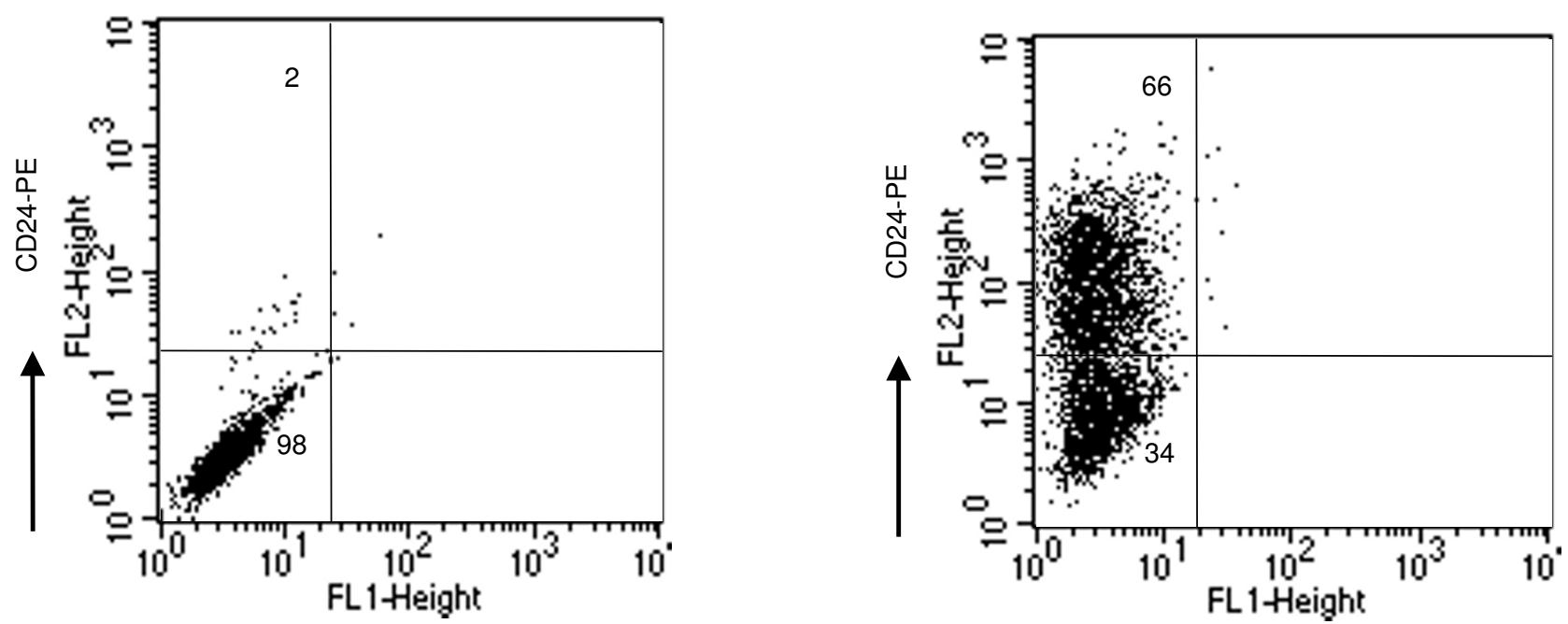

Figure I

CD24 expression in MDA-MB-23 I and MCF-7 cells by FACS (\%). MDA-MB-23I and MCF-7 cells were cultured in DMEM containing I0\% FBS for $72 \mathrm{~h}$. Flow cytometry analysis was performed with PE anti-human CD24 antibody on a FACSCalibur system. A representative result is shown.

A

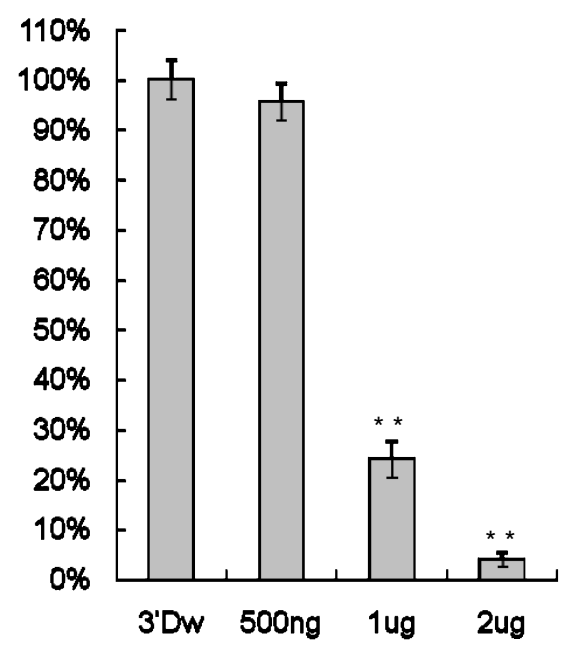

B

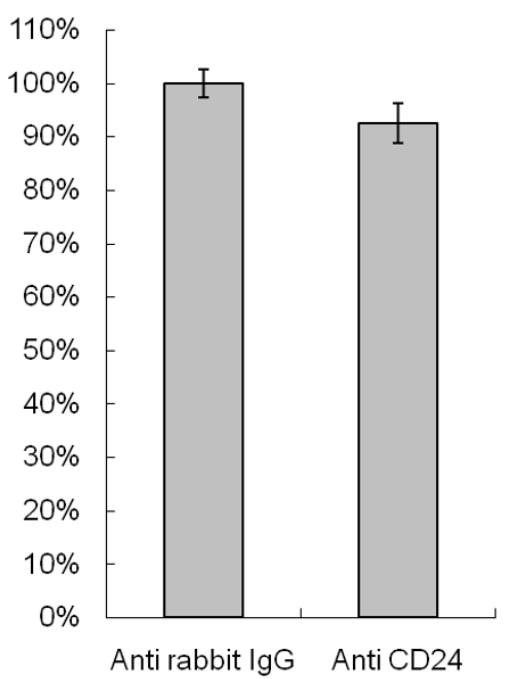

C
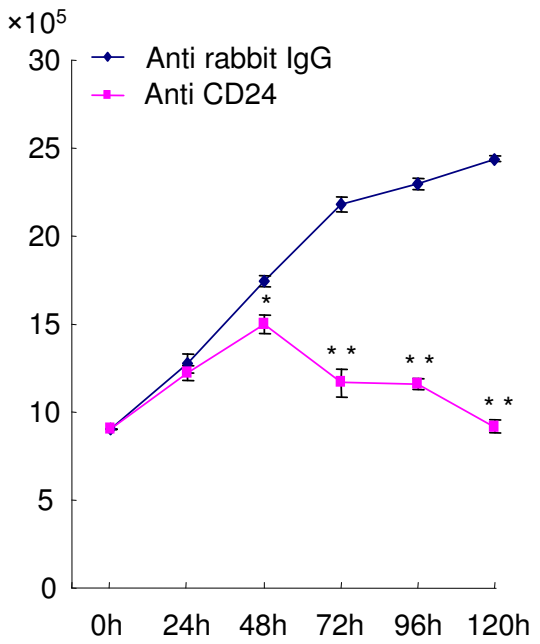

Figure 2

Viability of MDA-MB-23 I and MCF-7 cells after CD24 cross-linking. A) MCF-7 cross-linked with anti-rabbit polyclonal IgG in a dose dependent manner for $72 \mathrm{~h}$. B) MDA-MB-23I cells were cross-linked with $500 \mathrm{ng} / \mathrm{ml}$ anti-rabbit polyclonal lgG or anti-human CD24 rabbit polyclonal antibody for $72 \mathrm{~h}$. C). MCF-7 cells were cross-linked with $500 \mathrm{ng} / \mathrm{ml}$ anti-rabbit polyclonal IgG antibody or anti-human CD24 rabbit polyclonal antibody in a time dependent manner for I20 h. A-B) Relative cell survival rate is shown as percent survival versus control cells after cross-linking with anti-rabbit polyclonal IgG. C) MCF-7 cell survival is shown versus control cell survival when CD24 was cross-linked with anti-rabbit polyclonal lgG. Data represent means of at least three independent experiments and standard errors of the means. $*, p$ value of less than $0.05 * *, p$ value of less than 0.01 . 
nal IgG that exerted no effect on viability. MDA-MB-231 and MCF-7 cells were treated with $500 \mathrm{ng} / \mathrm{ml}$ anti-rabbit polyclonal IgG or $500 \mathrm{ng} / \mathrm{ml}$ anti-human CD24 rabbit polyclonal antibody. There was no change in MDA-MB231 cell growth (Fig. 2B). In contrast, MCF-7 cell growth decreased by $4 \%, 14 \%, 46 \%, 50 \%$, and $62 \%$ at timepoints of 24 h, 48 h, 72 h, 96 h, and 120 h, respectively (Fig. 2C).

\section{Inhibition of growth after CD24 cross-linking in three- dimensional culture}

Three-dimensional culture using matrigel was predicted to be a useful method for confirming the effect of cross- linking in vitro. We examined growth inhibition after CD24 cross-linking using matrigel containing ECM. MCF7 cells were cross-linked with anti-rabbit polyclonal IgG and anti-human CD24 rabbit polyclonal antibody at the $500 \mathrm{ng} / \mathrm{ml}$ dosage for $72 \mathrm{~h}$. When cultured on top of three-dimensional matrigel, MCF-7 cells cross-linked with anti-human CD24 rabbit polyclonal antibody decreased $15 \%$ compared to cells cross-linked with anti-rabbit polyclonal IgG (Fig. 3).

Cell cycle and apoptosis analyses after CD24 cross-linking We observed a decrease in cell number after CD24 crosslinking. To determine whether the cause of decreased cell

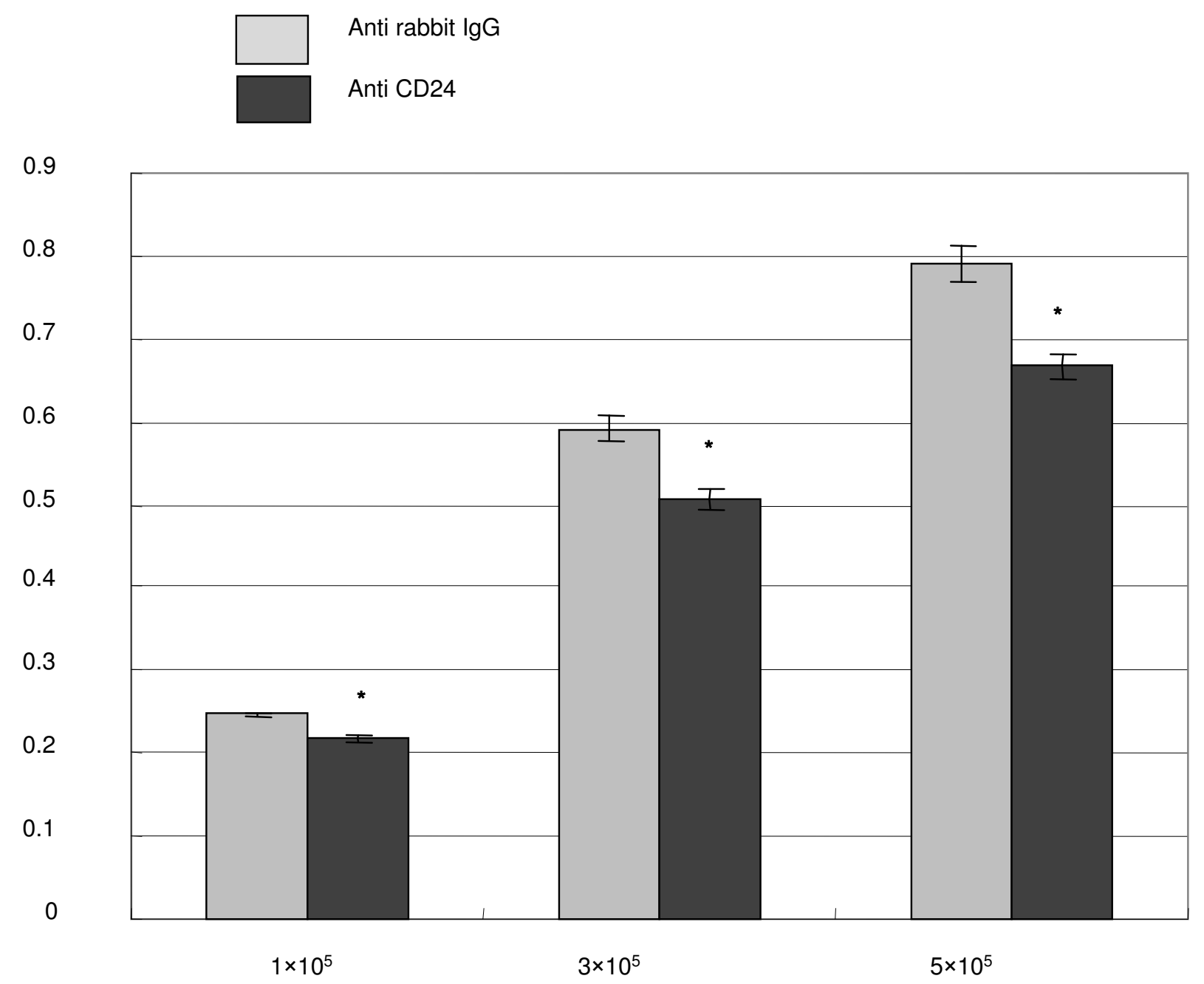

\section{Figure 3}

MCF-7 cell growth in three-dimensional culture. $1 \times 10^{5}, 3 \times 10^{5}$, and $5 \times 10^{5}$ cells were cultured in DMEM containing $10 \%$ FBS in the three-dimensional matrigel $(5 \mathrm{mg} / \mathrm{ml})$ for $24 \mathrm{~h}$ and then CD24 was cross-linked with $500 \mathrm{ng} / \mathrm{ml}$ anti-rabbit polyclonal IgG or anti-human CD24 rabbit polyclonal antibody for $72 \mathrm{~h}$. Cell viability in three-dimensional culture was examined by MTT assay. The data are shown as the absorbance of MCF-7 survival versus the control cell survival after CD24 cross-linking with anti-rabbit polyclonal IgG. Means of at least three independent experiments are compared and standard errors are shown. *, $p$ value of less than 0.05 . 
number was cell cycle arrest or apoptosis, we analyzed DNA content with propidium iodide solution and annexin $\mathrm{V}$ by flow cytometry. Stained DNA contents after CD24 cross-linking were similar in each cell type compared to after cross-linking with anti-rabbit polyclonal IgG (Fig. 4). In the apoptosis assay, cell population decreased by $10 \%$ and $26 \%$ at $72 \mathrm{~h}$ and $96 \mathrm{~h}$, respectively, exhibiting increased apoptosis after CD24 cross-linking (Fig. 5A,B).

\section{Effects of CD24 cross-linking on MCF-7 cell adhesion and migration}

We assumed that CD24 was a cell adhesion molecule in MCF-7 cells. MCF-7 was pre-treated with anti-rabbit polyclonal IgG or anti-human CD24 rabbit polyclonal antibody $(500 \mathrm{ng} / \mathrm{ml}$ ) for $24 \mathrm{~h}$. The adhesion capacity of harvested MCF-7 cells after CD24 cross-linking was not significantly reduced (Fig. 6A), but the number of migrating cells was reduced by $30 \%$ (Fig. 6B).

\section{Discussion}

CD24 is important for progression, migration, and metastasis of human breast cancer [8]. However, the specific functions of CD24 in breast cancer are unclear. Here, we showed that CD24 cross-linking is sufficient to inhibit tumor growth (Fig. 2C), and migration (Fig. 6B) in MCF7 breast cancer cells. Additionally, apoptosis increased upon CD24 cross-linking (Fig. 5).

Our results are in agreement with previous findings when Suzuki et al. [19] reported that CD24 cross-linking induced apoptosis in a human B-cell subset during the early activation stage through interactions with glycolipid-enriched membrane domains. Taguchi et al. [20] demonstrated that apoptosis observed upon cross-linking CD24 did not result from non-specific binding of either mouse immunoglobulin or secondary rabbit polyclonal anti-mouse immunoglobulin antibody, but from treatment with a combination of anti-CD24 and rabbit antimouse immunoglobulin antibodies in KM-3 pro-B cells. To confirm that the apoptosis observed upon cross-linking of CD24 was not resulting from the non-specific binding of secondary rabbit polyclonal antibodies, MCF-7 cells were cross-linked with anti-human CD24 (SN3) mouse monoclonal antibody raised against NALM-1 human pre-B leukemia cell line. Effect of cross-linking with anti-human CD24 (SN3) mouse monoclonal antibody was similar to what was observed anti-human CD24 (FL-80) rabbit polyclonal antibody (Additional files. 2, 3). Several analogous reports documented proliferation and apoptosis in human B-cells [19] and murine thymocytes [21] after CD24 cross-linking.

In contrast to our findings, Schabath and colleagues showed that MDA-MB-231 cells (used as a control in this study) transfected to express CD24 had reduced migration and tumor growth in NOD/SCID mice [22]. We crosslinked CD24 in MCF-10A breast cells expressing CD24 and observed inhibited growth in the CD24 expressing cells (Additional files. 1), similar to what was observed in MCF-7 cells.

We found that CD24 cross-linking exhibited an inhibitory effect on breast cancer cell growth in the three-dimen-
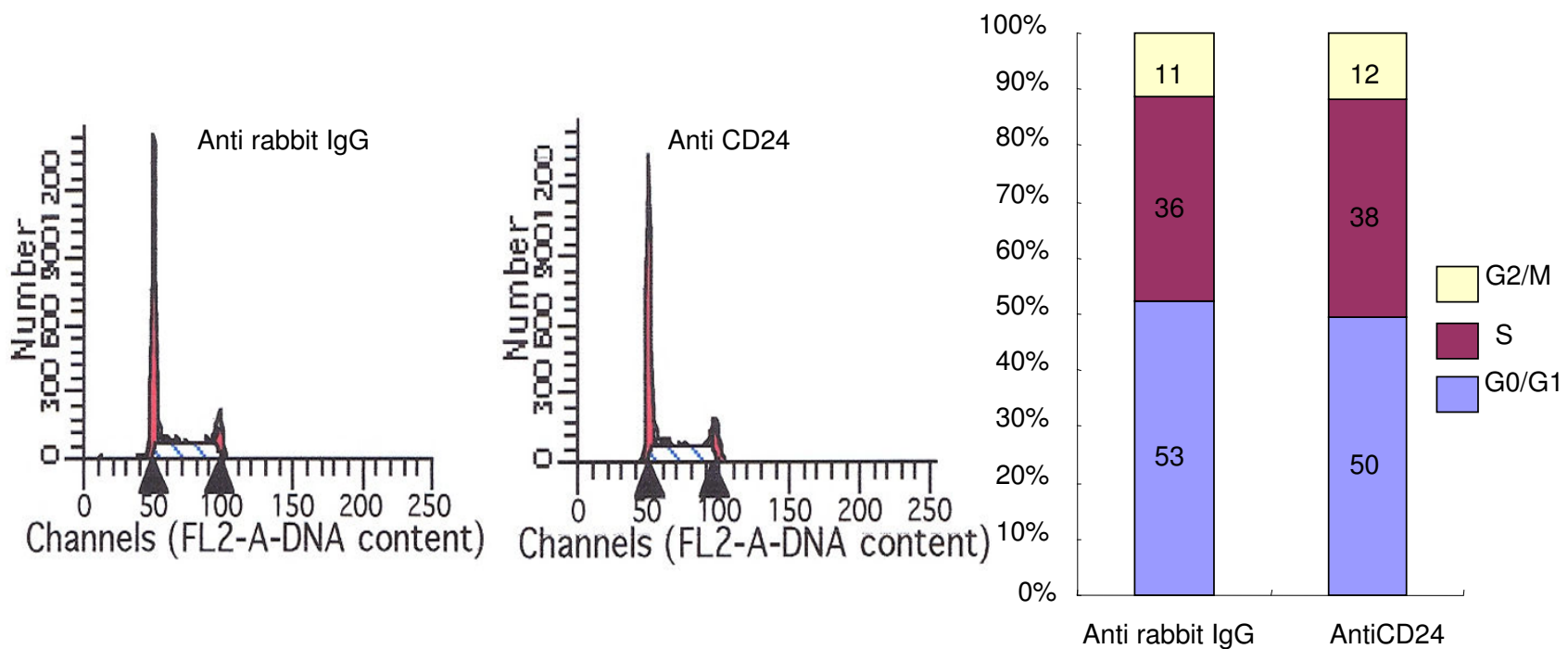

Figure 4

Changes in cell cycle after CD24 cross-linking $72 \mathrm{~h}$. The cell cycle was analyzed by FACS after DNA staining with propidium iodide and a representative experiment (from three total) is shown. 

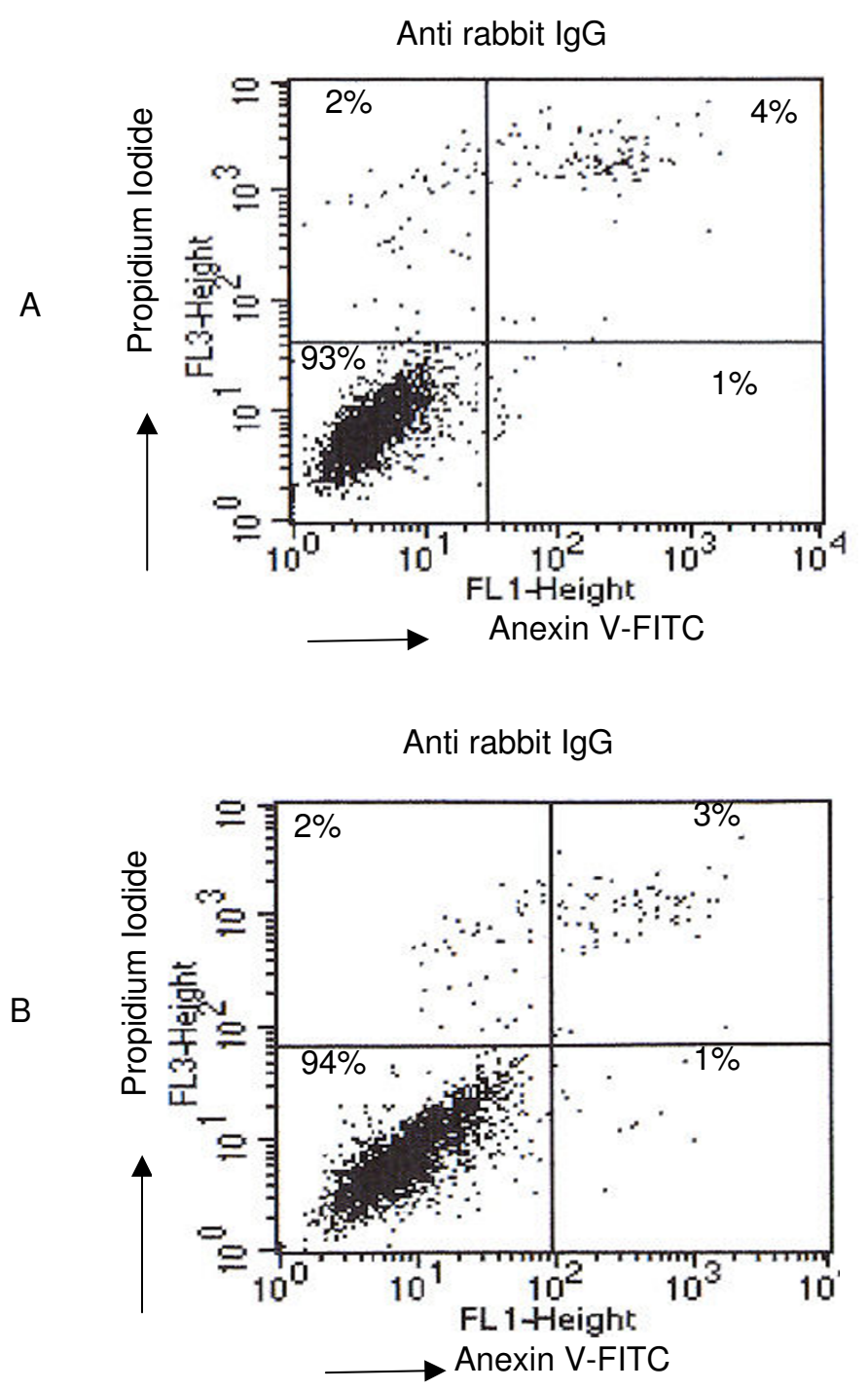

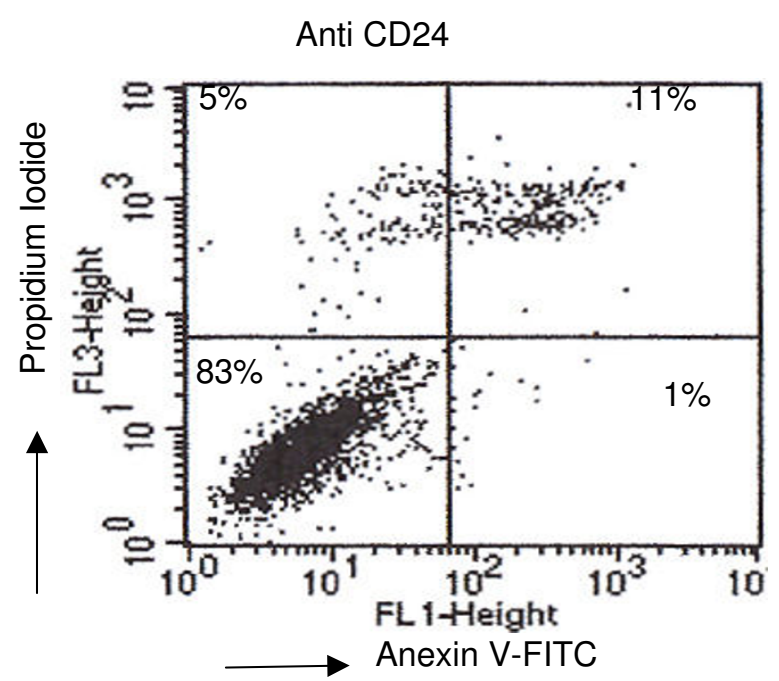

Anti CD24

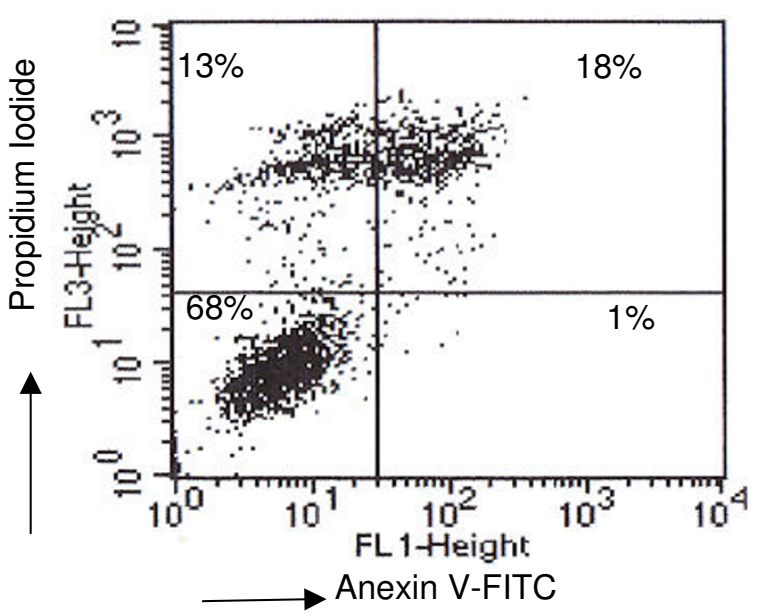

\section{Figure 5}

Changes in apoptosis after CD24 cross-linking. A) Cross-linking for 72 h. B) Cross-linking for 96 h. Cells were stained with FITC-conjugated annexin $\mathrm{V}$ in a buffer containing propidium iodide and analyzed by flow cytometry. For each group of cells, the percentage of survival is shown in the lower left quadrant, where both in annexin $V$ and propidium iodide levels are low. One of three representative experiments is presented.

sional culture system. In agreement with our findings, Wang et al. [23] reported a reduction in T-cell proliferation upon blockage with an anti-HSA antibody. Moreover, cross-linking of CD24 induced apoptosis in murine thymocytes [21]. Jung and colleagues [21] demonstrated that apoptosis triggered by CD24 cross-linking results in the generation of reactive oxygen species (ROS), and that the release of apoptosis inducing factor (AIF) does not lead to caspase activation in murine thymocytes.

Migration capacities of MCF-7 cells were reduced by $30 \%$ after CD24 cross-linking. Our results further indicate that
CD24 is involved in migration in MCF-7 cells, and imply that tumor progression can be inhibited by CD24 crosslinking (Fig. 6B). Using in vitro migration assays (matrigel) and in vivo immunohistochemical staining, Senner et al. [7] have found, in a rat model, that CD24positive gliomas are more aggressive than CD24 negative implants, but did not observe a greater migration rate of CD24-positive cells in matrigel assays, which is in concordance with our data. CD24 is an adhesion molecule [2] and during tumor progression, adhesion to the extracellular matrix (ECM) is the initial step for invasion and metastasis [24]. In our study the adhesion of MCF-7 cells was 
A

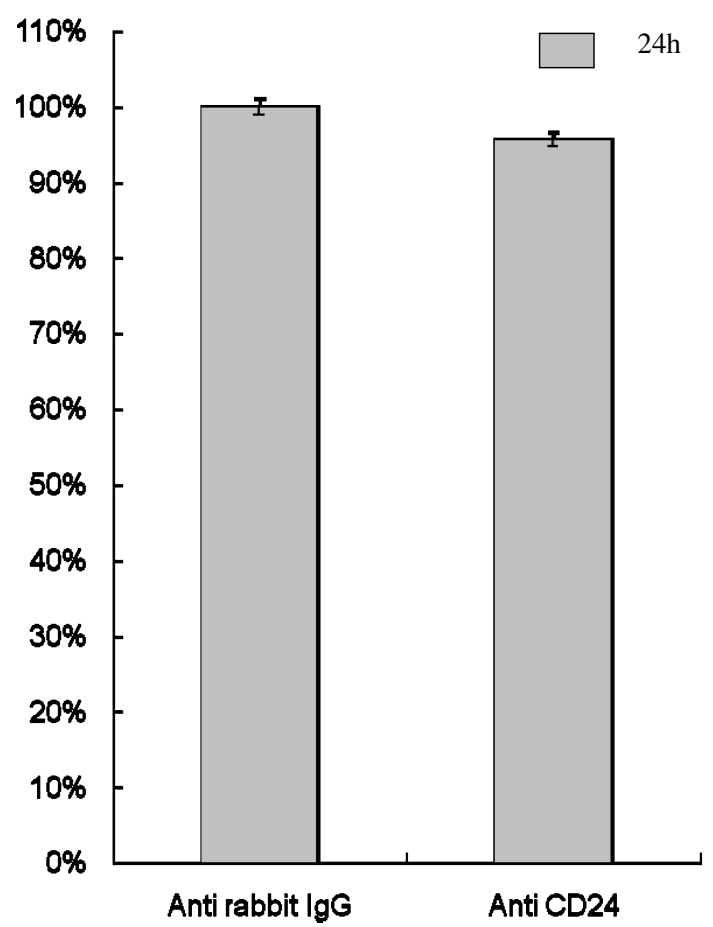

B

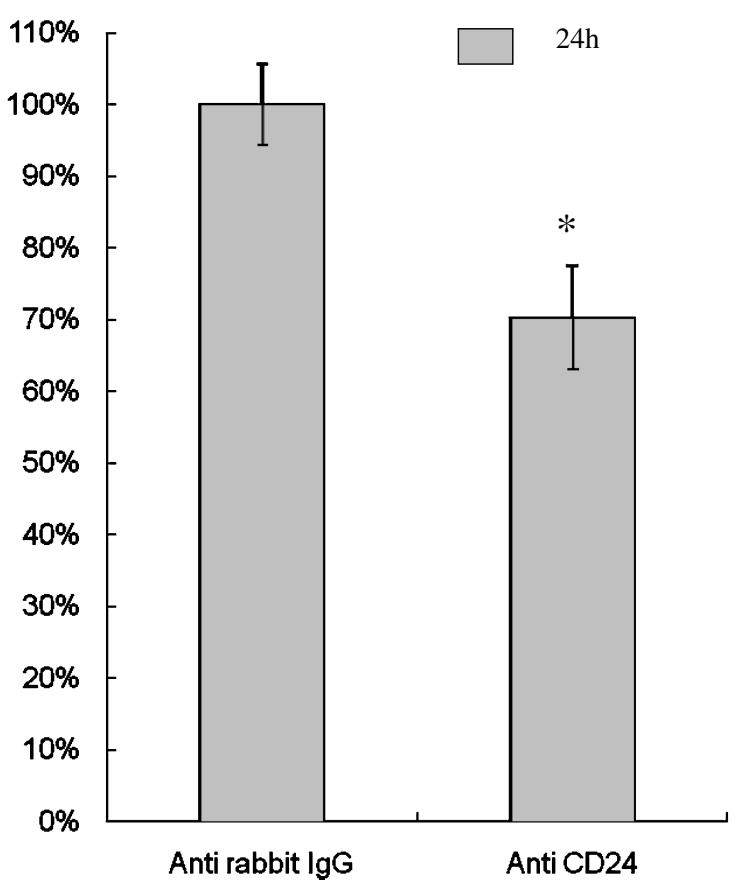

Figure 6

Effects of CD24 cross-linking on the adhesion and migration capacity of MCF-7 cells. A) Relative adhesion rate in the data is shown as percent adherent cells versus control cells where CD24 was cross-linked with anti-rabbit polyclonal lgG. B) Relative migrating cell rate is shown as percent migrating cells versus control cells where CD24 was cross-linked with antirabbit polyclonal lgG. *, $p$ value of less than 0.05 .

reduced slightly, but not significantly after CD24 crosslinking.

Interestingly, we observed variable expression rates of CD24 in both control and MCF-7 cells. Figure 1 depicts CD24 expression in $2 \%$ of control cells and $66 \%$ of MCF7 cells. However, expression levels of CD24 in MCF-7 cells ranged from $66 \%$ to $98 \%$, depending on the passage number and culture conditions, including culture medium serum composition (data not shown). A number of reports show that alterations in protein expression are dependent on the culture environment. For instance, serum in MCF-10A cell culture plays an important role in CD24 expression [11]. Estrogen-receptor expression is altered in MCF-7 and BT474 cells depending on the passage number [25].

Recently, CD44+CD24-/low lineage-cells were implicated in breast cancer initiated tumorigenesis in NOD/SCID mice [26]. This work suggested that the tumor initiating cells were cancer stem cells. Furthermore, early cancer cells detected in bone marrow of breast cancer patients were observed to have breast cancer stem sell phenotype [27], but the frequency of CD44+/CD24-/low cells in breast cancer tissue was not correlated with clinical outcome [28]. CD24 was suggested as a marker of luminal cells in the breast [29], and a previous report indicated the existence of progenitor cells in luminal epithelia which could be reflective of myoepithelial cells [30]. On the other hand, normal stem cells have been isolated using CD24, CD29, and CD49f in mouse mammary glands [31,32], so a single, definitive breast cancer stem cell marker has yet to be defined.

\section{Conclusion}

In conclusion, we demonstrated that CD24 cross-linking induced apoptosis and inhibited migration ability in MCF-7 human breast cancer cells. It is possible that CD24 in vivo may be a novel target for breast cancer treatment.

\section{Competing interests}

The authors declare that they have no competing interests. 


\section{Authors' contributions}

All the authors contributed to the conception of the work during the initial stages and study design, analysis and interpretation of the data, as well as drafting and critical revision of the important intellectual content. All authors approved the final version of the manuscript to be published. JBK and EK have equally contributed to all parts of this study. DYN and WH were in charge of the general supervision of the research. The order of authorship was based on a joint decision.

\section{Additional material}

\section{Additional file 1}

CD24 expression and cell viability after CD24 cross-linking in MCF10A cells. A) CD24 expression was analysed with PE anti-human CD24 antibody by flow cytometry on a FACSCalibur system. One of three the representative experiments are shown in the result. B) MCF-10A was cross-linked with $500 \mathrm{ng} / \mathrm{ml}$ anti-rabbit polyclonal IgG or anti-human CD24 rabbit polyclonal antibody $72 \mathrm{~h}$. B) Relative survival cell rate is shown as percent survivals versus in treatment versus control cells where CD24 was cross-linked with anti-rabbit polyclonal IgG. C). MCF-10A was treated with $500 \mathrm{ng} / \mathrm{ml}$ of anti-rabbit polyclonal IgG or anti-human CD24 rabbit polyclonal antibody in a time dependent manner for $72 \mathrm{~h}$. C) MCF-10A cell survival is shown versus control cell survival after CD24 cross-linking with anti-rabbit polyclonal IgG. Means of at least three independent experiments are presented with standard errors. ${ }^{*}, \mathrm{p}$ value of less than $0.05 * *, \mathrm{p}$ value of less than 0.01 .

Click here for file

[http://www.biomedcentral.com/content/supplementary/14712407-8-118-S1.ppt]

\section{Additional file 2}

Viability of MCF-7 cross-linked with anti-human CD24 mouse monoclonal antibody. A) MCF-7 cells were cross-linked with anti-mouse monoclonal IgG antibody in a dose dependent manner for $72 \mathrm{~h}$. B) MCF7 cells were cross-linked with $500 \mathrm{ng} / \mathrm{ml}$ anti-mouse monoclonal IgG antibody or anti-human CD24 mouse monoclonal antibody for $72 \mathrm{~h}$. A-B) Relative survival cell rate is shown as percent survivals versus in treatment versus control cells where CD24 was cross-linked with anti-mouse monoclonal IgG. Data represent means of at least three independent experiments and standard errors of the means. ${ }^{*}, \mathrm{p}$ value of less than 0.01 . Click here for file

[http://www.biomedcentral.com/content/supplementary/14712407-8-118-S2.ppt]

\section{Additional file 3}

Changes in apoptosis after CD24 cross-linking with anti-human CD24 mouse monoclonal antibody. MCF-7 cells were cross-linked with $500 \mathrm{ng} / \mathrm{ml}$ anti-mouse monoclonal IgG antibody or anti-human CD24 mouse monoclonal antibody for $72 \mathrm{~h}$. Cells were stained with FITC-conjugated annexin $V$ in a buffer containing propidium iodide and analyzed by flow cytometry. For each group of cells, the percentage of survival is shown in the lower left quadrant, where both in annexin $V$ and propidium iodide levels are low. One of three representative experiments is presented. Click here for file

[http://www.biomedcentral.com/content/supplementary/14712407-8-118-S3.ppt]

\section{Acknowledgements}

This study was supported by grants No. 03-2005-008-0 from the Clinical Research Institute, Seoul National University Hospital, and SC-3I80 from the Stem Cell Research Center, 2 Ist Century Frontier R\&D Program, funded through the Ministry of Science \& Technology of Korea.

\section{References}

I. Baumann P, Cremers N, Kroese F, Orend G, Chiquet-Ehrismann R, Uede T, Yagita H, Sleeman JP: CD24 expression causes the acquisition of multiple cellular properties associated with tumor growth and metastasis. Cancer research 2005, 65(23): 10783-10793.

2. Magnaldo $\mathrm{T}$, Barrandon $\mathrm{Y}$ : CD24 (heat stable antigen, nectadrin), a novel keratinocyte differentiation marker, is preferentially expressed in areas of the hair follicle containing the colony-forming cells. Journal of cell science 1996, I09(Pt (3):3035-3045

3. Kristiansen G, Sammar M, Altevogt P: Tumour biological aspects of CD24, a mucin-like adhesion molecule. I Mol Histol 2004, 35(3):255-262.

4. Aigner S, Ruppert M, Hubbe M, Sammar M, Sthoeger Z, Butcher EC, Vestweber D, Altevogt P: Heat stable antigen (mouse CD24) supports myeloid cell binding to endothelial and platelet $\mathbf{P}$ selectin. Int Immunol I995, 7( I 0): I557-I565.

5. Friederichs J, Zeller Y, Hafezi-Moghadam A, Grone HJ, Ley K, Altevogt $P$ : The CD24/P-selectin binding pathway initiates lung arrest of human AI25 adenocarcinoma cells. Cancer research 2000, 60(23):67I4-6722.

6. Choi YL, Lee SH, Kwon GY, Park CK, Han JJ, Choi JS, Choi HY, Kim $\mathrm{SH}$, Shin YK: Overexpression of CD24: association with invasiveness in urothelial carcinoma of the bladder. Archives of pathology \& laboratory medicine 2007, I 3 I (2):275-28I.

7. Senner V, Sturm A, Baur I, Schrell UH, Distel L, Paulus W: CD24 promotes invasion of glioma cells in vivo. J Neuropathol Exp Neurol 1999, 58(8):795-802.

8. Kristiansen G, Winzer KJ, Mayordomo E, Bellach J, Schluns K, Denkert C, Dahl E, Pilarsky C, Altevogt P, Guski H, et al.: CD24 expression is a new prognostic marker in breast cancer. Clin Cancer Res 2003, 9(13):4906-4913.

9. Aigner S, Ramos CL, Hafezi-Moghadam A, Lawrence MB, Friederichs J, Altevogt P, Ley K: CD24 mediates rolling of breast carcinoma cells on P-selectin. Faseb J I998, I 2(I 2): | 24|-|25I.

10. Surowiak P, Materna V, Paluchowski P, Matkowski R, Wojnar A, Maciejczyk A, Pudelko M, Kornafel J, Dietel M, Kristiansen G, et al: CD24 expression is specific for tamoxifen-resistant ductal breast cancer cases. Anticancer research 2006, 26(I B):629-634.

II. Sheridan C, Kishimoto H, Fuchs RK, Mehrotra S, Bhat-Nakshatri P, Turner CH, Goulet R Jr, Badve S, Nakshatri H: CD44+/CD24breast cancer cells exhibit enhanced invasive properties: an early step necessary for metastasis. Breast Cancer Res 2006, 8(5):R59.

12. Oesterreich S, Zhang P, Guler RL, Sun X, Curran EM, Welshons WV, Osborne CK, Lee AV: Re-expression of estrogen receptor alpha in estrogen receptor alpha-negative MCF-7 cells restores both estrogen and insulin-like growth factor-mediated signaling and growth. Cancer research 200I, 6I(I 5):577I-5777.

13. Long $X$, Nephew KP: Fulvestrant (ICI 182,780)-dependent interacting proteins mediate immobilization and degradation of estrogen receptor-alpha. The Journal of biological chemistry 2006, 28 I (14):9607-96I5.

14. Charafe-Jauffret E, Ginestier C, Monville F, Finetti P, Adelaide J, Cervera N, Fekairi S, Xerri L, Jacquemier J, Birnbaum D, et al.: Gene expression profiling of breast cell lines identifies potential new basal markers. Oncogene 2006, 25(I 5):2273-2284.

15. Liu $\mathrm{W}$, Vadgama JV: Identification and characterization of amino acid starvation-induced CD24 gene in MCF-7 human breast cancer cells. International journal of oncology 2000, 16(5): 1049-1054

16. Miller MA, Lippman ME, Katzenellenbogen BS: Antiestrogen binding in antiestrogen growth-resistant estrogen-responsive clonal variants of MCF-7 human breast cancer cells. Cancer research I 984, 44(II):5038-5045.

17. Lim SC, Oh SH: The role of CD24 in various human epithelia neoplasias. Pathology, research and practice 2005, 20 I (7):479-486. 
18. Fogel M, Friederichs J, Zeller Y, Husar M, Smirnov A, Roitman L, Altevogt P, Sthoeger ZM: CD24 is a marker for human breast carcinoma. Cancer letters 1999, I43(I):87-94.

19. Suzuki T, Kiyokawa N, Taguchi T, Sekino T, Katagiri YU, Fujimoto J: CD24 induces apoptosis in human B cells via the glycolipidenriched membrane domains/rafts-mediated signaling system. J Immunol 200I, I 66(9):5567-5577.

20. Taguchi T, Kiyokawa N, Mimori K, Suzuki T, Sekino T, Nakajima H, Saito M, Katagiri YU, Matsuo N, Matsuo Y, et al.: Pre-B cell antigen receptor-mediated signal inhibits CD24-induced apoptosis in human pre-B cells. J Immunol 2003, I 70(I):252-260.

21. Jung KC, Park WS, Kim HJ, Choi EY, Kook MC, Lee HW, Bae Y: TCR-independent and caspase-independent apoptosis of murine thymocytes by CD24 cross-linking. I Immunol 2004, I 72(2):795-802.

22. Schabath H, Runz S, Joumaa S, Altevogt P: CD24 affects CXCR4 function in pre-B lymphocytes and breast carcinoma cells. Journal of cell science 2006, I I 9(Pt 2):3 |4-325.

23. Wang YC, Sashidharamurthy R, Nagarajan S, Selvaraj P: B7-I-HSA (CD80-CD24), a recombinant hybrid costimulatory molecule retains ligand binding and costimulatory functions. Immunology letters 2006, I 05(2): I85-192.

24. Hough MR, Rosten PM, Sexton TL, Kay R, Humphries RK: Mapping of CD24 and homologous sequences to multiple chromosomal loci. Genomics 1994, 22(I): I54-I6I.

25. Lostumbo A, Mehta D, Setty S, Nunez R: Flow cytometry: a new approach for the molecular profiling of breast cancer. Exp Mol Pathol 2006, 80(I):46-53.

26. Al-Hajj M, Wicha MS, Benito-Hernandez A, Morrison SJ, Clarke MF: Prospective identification of tumorigenic breast cancer cells. Proceedings of the National Academy of Sciences of the United States of America 2003, I 00(7):3983-3988.

27. Balic M, Lin H, Young L, Hawes D, Giuliano A, McNamara G, Datar $\mathrm{RH}$, Cote RJ: Most early disseminated cancer cells detected in bone marrow of breast cancer patients have a putative breast cancer stem cell phenotype. Clin Cancer Res 2006, I 2(19):56|5-562I.

28. Abraham BK, Fritz P, McClellan M, Hauptvogel P, Athelogou M, Brauch H: Prevalence of CD44+/CD24-/low cells in breast cancer may not be associated with clinical outcome but may favor distant metastasis. Clin Cancer Res 2005, I I (3): I I 54- I I 59.

29. Sleeman KE, Kendrick H, Ashworth A, Isacke CM, Smalley MJ: CD24 staining of mouse mammary gland cells defines luminal epithelial, myoepithelial/basal and non-epithelial cells. Breast Cancer Res 2006, 8(I):R7.

30. Gudjonsson T, Villadsen R, Nielsen HL, Ronnov-Jessen L, Bissell MJ, Petersen OW: Isolation, immortalization, and characterization of a human breast epithelial cell line with stem cell properties. Genes \& development 2002, I 6(6):693-706.

31. Kordon EC, Smith GH: An entire functional mammary gland may comprise the progeny from a single cell. Development (Cambridge, England) 1998, I 25(1 0): 1921-1930.

32. Shackleton M, Vaillant F, Simpson KJ, StingI J, Smyth GK, Asselin-Labat ML, Wu L, Lindeman GJ, Visvader JE: Generation of a functional mammary gland from a single stem cell. Nature 2006, 439(7072):84-88.

\section{Pre-publication history}

The pre-publication history for this paper can be accessed here:

http://www.biomedcentral.com/1471-2407/8/118/pre pub

\section{Publish with Biomed Central and every scientist can read your work free of charge}

"BioMed Central will be the most significant development for disseminating the results of biomedical research in our lifetime. "

Sir Paul Nurse, Cancer Research UK

Your research papers will be:

- available free of charge to the entire biomedical community

- peer reviewed and published immediately upon acceptance

- cited in PubMed and archived on PubMed Central

- yours - you keep the copyright
BioMedcentral 